\title{
Quality Attributes of Cobia (Rachycentron canadum) Fillets Chilled and Packaged in Modified Atmospheres
}

\author{
Marcondes Agostinho Gonzaga Junior ${ }^{1 *}$, Marianna Basso Jorge ${ }^{2}$, William Renzo Cortez-Vega ${ }^{3}$, Sandriane Pizato ${ }^{4}$ and Carlos Prentice- \\ Hernández ${ }^{4}$
}

${ }^{1}$ Estacao Marine Aquaculture, Oceanography Institute, Federal University of Rio Grande, Rio Grande, RS - Brazil

2Institute of Biological Sciences, Federal University of Rio Grande, Rio Grande, RS - Brazil

${ }^{3}$ Faculty of Engineering, Laboratory of Bioengineering, University of Grande Dourados, Dourados, MS - Brazil

${ }^{4}$ School of Chemistry and Food, Federal University of Rio Grande, Rio Grande, RS - Brazil

\begin{abstract}
The aim of the present work was to evaluate the effects of modified atmospheres packaging (MAP) on cobia (Rachycentron canadum) fillets. The specimens used were filleted and packed in high-density ethylene-vinyl alcohol plastic bags and then submitted to 3 treatments: A (control atmosphere air condition), B (vacuum atmosphere condition) and C ( $100 \% \mathrm{CO}_{2}$ atmosphere condition), B (vacuum) and $\mathrm{C}\left(100 \% \mathrm{CO}_{2}\right)$. The packaged samples were maintained under cooling temperature of $2 \pm 1^{\circ} \mathrm{C}$. Samples were submitted to different analysis (TVB-N, pH, TBA, texture, color and microbiology) during the storage period (zero, $1,7,14,21,30$ and 45 days). Samples stored under aerobic conditions (A) showed fast increase of TVB-N and an increase of $\mathrm{pH}$ values. The TBA indexes remained below $3.5 \mathrm{mg} \mathrm{kg}^{-1}$ for all treatments and the color patterns varied slightly while the texture analyses varied from 2.05 to $6.61 \mathrm{~N}$. From the results of the chemical and microbiological analyses, it can be concluded that the treatments $(B)$ and $(C)$ presented satisfactory results for the storage test period. MAP treatment $(C)$, different for the other ones, presented discolored fillets with softer texture. Vacuum packing, proved as the best treatment, maintained the best stability condition for chemical, microbiological and sensory characteristics throughout the experiment, extending the shelf life of cobia fillets for 30 days.
\end{abstract}

Keywords: Cobia; Fillets; Modified atmosphere packaging; Shelf life; Quality deterioration

\section{Introduction}

Cobia (Rachycentron canadum) is a relatively new species to marine aquaculture. Due to its excellent characteristics as fillet quality, high commercial prices and fast growth, this species has been considered to be a noteworthy candidate for aquaculture [1], with great potential for global production. Commercially, it has been cultivated in ponds, net pens and recirculating systems, exhibiting great's resistance to diseases and flesh quality $[2,3]$. However, little is known about cobia processing. Generally, seafood quality, that is a perishable product, is influenced by the freshness of the product. Actually, it is known that fish shelf life could be determined by the intensity of enzymatic reactions and the number and species of microorganisms that occurs before the product being consumed. Other determinants characteristics, which should be evaluated at all stages of production, are the storage temperature, temperature during capture, delayed cooling and temperature retail. Combined methods have been used to improve the quality of conventional products and develop new ones. They ensure the stability and safety by providing better sensory and nutritional properties to consumers [4]. Shelf life extension of packaged fish under MAP conditions has been reported from 50 to 400 percent, but only the period of moderate to low quality is often prolonged, not the initial period of prime quality [5]. Usually the effect of MAP is conditioned by the concentrations and amount of $\mathrm{CO}_{2}$ and $\mathrm{O}_{2}$ available in the gas atmosphere, quality of raw materials, and the most importantly, storage temperature [6]. The presence of $\mathrm{CO}_{2}$ inhibits growth of the normal spoilage flora in air (such as Pseudomonas and Shewanella putrefaciens) promoting the growth of microorganisms tolerant to $\mathrm{CO}_{2}$ (such as Lactobacillus spp., Photobacterium phosphoreum, Brochothrix thermosphacta) during the storage time. Usually only one species is responsible for the main sensory spoilage, called specific spoilage organisms (SSO). The numbers of SSO and the concentration of their metabolites can be used as objective indices of spoilage in shelf life determination [7]. At high concentrations of $\mathrm{CO}_{2}, P$. phosphoreum was found as the main spoilage bacteria, both in MA packaged chilled cod [8] as salmon [9]. The applicability of knowledge on specific spoilage organisms is of vital importance for determining, predicting and extending shelf life of the product, obtaining higher quality raw material for a longer period. Modified atmosphere packaged foods have become more available to meet consumer demand for fresh and refrigerated foods with extended shelf lives, being extensively used to fresh meat, poultry and fish products, among others [10,11]. The principle of MAP is the replacement of packaged air with a different fixed gas mixture. Carbon dioxide $\left(\mathrm{CO}_{2}\right)$ is the most important gas used in MAP since it has bacteriostatic and fungistatic properties [12]. His presence changes the $\mathrm{pH}$ of the product acting as a barrier against some spoilage bacteria. That way, storage under MAP conditions extends the shelf life of the product, delaying the rate of spoilage. The success of MAP depends of many factors, including good initial product quality, good hygiene during slaughter, correct packing, packing equipments, appropriate gas mixture, proportional rate of gas and product volume $(\mathrm{g} / \mathrm{p})$, and the temperature during the entire process [13]. However, the amount of $\mathrm{CO}_{2}$ dissolved into the product and the storage temperature are the most critical factors [14]. Although it is proven that the use of MAP provides improvements in the preservation of fish, the unification

*Corresonding author: Marcondes Agostinho Gonzaga Junior, Postgraduate Certificate in Aquaculture, Federal University of Rio Grande, Oceanography Institute, Av. Italy 8 km, Campus Carreiros, 96.201-900, Rio Grande-RS, Brazil, Tel: +55 53 3233-8621; Fax: +55 53 3233-8745; E-mail: jrgonzaga@bol.com.br

Received March 05, 2015; Accepted March 27, 2015; Published April 06, 2015

Citation: Junior MAG, Jorge MB, Cortez-Vega WR, Pizato S, Prentice-Hernández C (2015) Quality Attributes of Cobia (Rachycentron canadum) Fillets Chilled and Packaged in Modified Atmospheres. J Food Process Technol 6: 445 doi:10.4172/2157-7110.1000445

Copyright: @ 2015 Junior MAG, et al. This is an open-access article distributed under the terms of the Creative Commons Attribution License, which permits unrestricted use, distribution, and reproduction in any medium, provided the original author and source are credited. 
of criteria becomes difficult when we takes into consideration the difference between species, mixtures of gases and temperatures of storage. Work using MAP in salmon fillets [15], slices [16] and steaks [17] showed that sensory shelf life of the products were extended to 20 , 18 and 22 days, respectively. Sivertsvik et al. [6] studied the evolution of the storage conditions of salmon fillets in controlled cooling $\left(4^{\circ} \mathrm{C}\right)$ and MAP $\left(\mathrm{CO}_{2}: \mathrm{N}_{2} ; 60: 40\right)$ conditions, found that the best performance of sensory shelf life was 21 days. Sivertsvik et al. [18] also studied the quality of cooling $\left(\leq 1^{\circ} \mathrm{C}\right)$ during transport of gutted salmon (Salmo salar) stored in plastic bags containing 50 and $100 \%$ of $\mathrm{CO}_{2}, 60 \%$ of $\mathrm{CO}_{2}$ and $40 \%$ of $\mathrm{O}_{2}$, as well as conventional packaging (polystyrene) material. The authors found that salmon packed in MAP showed better sensory quality after 13 days of storage than conventionally packaged. The experiments cited above were performed in different gas mixtures, $\mathrm{gp}^{-1}$ ratios and temperatures. Taking into account the excellent potential of cobia to aquaculture and the high quality of their fillets, the present work aims to develop a product of convenience, cobia minimally processed, by the determination of your shelf life through monitoring their chemical and physical properties, as well as the performance of microbiological evaluations.

\section{Material and Methods}

\section{Packaging and storage condition}

Cobia specimens were obtained from a fish farm in Angra dos Reis - RJ, southern Brazil. Fishes were killed by immersion in ice cold water (hypothermia), gutted and packed in an insulated polystyrene ice box. They were then delivered to the laboratory within $12 \mathrm{~h}$ after collection. Once in the laboratory, the fishes were washed, cleaned, filleted (about $200 \mathrm{~g}$ ) and packaged in modified atmosphere using a packaging machine (TECMAQ, model AP - 450). Fishes were packed with a film of ethylene vinyl alcohol - EVOH (transmission rate for oxygen of $28.18 \mathrm{~cm}^{3} \mathrm{~m}^{-2} \mathrm{day}^{-1}$ at $23^{\circ} \mathrm{C}, 80 \% \mathrm{RH}$ and $\left.1 \mathrm{~atm}\right)$. The ratio between the volume of gas and food weight used $(\mathrm{g} / \mathrm{p}$ ratio) was $2: 1(\mathrm{v} / \mathrm{w})$. The compositions of the gas mixture used for packaging the products were: A (control, atmosphere air condition), B (vacuum atmosphere condition) and $\mathrm{C}\left(100 \% \mathrm{CO}_{2}\right.$ atmosphere condition). All samples were stored in a refrigerator at a constant temperature $\left(2 \pm 1^{\circ} \mathrm{C}\right)$ for 45 days. Analyses were performed immediately (time 0 ) on packaging and after $1,7,14,21,30$ and 45 days of storage.

\section{Proximate composition}

Moisture, ash, crude protein and fat contents were determined according to the methods described by [19]. Moisture was determined by the oven drying method at $110^{\circ} \mathrm{C}$ for $24 \mathrm{~h}$. Total protein content was determined by the Kjeldhal method. Total lipids were assessed by the Soxhlet method.

\section{Chemical analysis}

Total Volatile Base Nitrogen (TVB-N) was determined by protein precipitation using trichloroacetic acid (TCA, 7.5\%) and evaluation of the total volatile base nitrogen in the TCA extract using the Micro Kjeldhal method, adapted by Jesus [20]. Thiobarbituric Acid Reactive Substances (TBARS) was determined by the precipitation of proteins associated with lipids and phospholipids. The spectrophotometer reading was taken at $538 \mathrm{~nm}$, using conversion factor to transform $\mathrm{mg}$ of malondialdehyde to $\mathrm{kg}$ of food, according to adapted Tarladgis et al. [21].

$\mathrm{pH}$ measurements was determined with the aid of a Digimed digital potentiometer, using muscle homogenized in distilled water in a proportion of 1:1, according to Analytical Norms of IAL [22]. The $\mathrm{pH}$ meter was calibrated with buffer solutions ( $\mathrm{pH} 4$ and $\mathrm{pH} 7$ ) at $20^{\circ} \mathrm{C}$.

\section{Physical analysis}

Fillet color was measured with a Tristimulous colorimeter method (CR-400 Chroma Meter, Konica Minolta Instrument Systems) with circular measurement area of $8 \mathrm{~mm}$. The colorimeter was calibrated using a white standard plate $(\mathrm{L}=100)$. The $\mathrm{L}^{\star}, \mathrm{a}^{\star}, \mathrm{b}^{\star}$ and $\mathrm{C}$ values were measured in three distinct position of the fillet. Three readings were carried out at each position. Texture analysis of cobia fillets was carried out using a texture analyzer Model TA-XT2 plus (Stable Micro Systems, Surrey, UK) calibrated for cutting speed $\left(2 \mathrm{~mm} \mathrm{~s}^{-1}\right)$, speed of return $\left(5 \mathrm{~mm} \mathrm{~s}^{-1}\right)$ and sensitivity $(0.250 \mathrm{~N})$. Samples were removed in form of parallelepipeds of $2 \mathrm{~cm}^{3}$, following the orientation of muscle fibers as Sigurgisladottir et al. [23], and submitted to a cutting/shearing test using Warner-Bratzler shear force (kgf), which indicated the total energy (work) required to shear (toughness). Results were transformed and expressed as newton unit.

\section{Microbiological analysis}

Samples ( $25 \mathrm{~g})$ were taken aseptically from the fish fillet, transferred aseptically to a stomacher bag (Seward Medical, London, UK) containing $225 \mathrm{~mL}$ of sterile peptone water $(0.1 \%)$ and homogenized with a stomacher (Lab Blender 400, Seward Medical) for $60 \mathrm{~s}$ at room temperature. Serial dilutions were prepared in sterile peptone water $(0.1 \%)$ and the surface was plated in duplicate on a standard plate count Agar (Acumedia Manufacturers, Inc., Lansing, MI) for the enumeration of microorganisms (aerobic mesophilic and psychrotrophic). Plates for mesophilic counts were stored at $35^{\circ} \mathrm{C}$ for $48 \mathrm{~h}$, while plates for psychrotrophic counts were stored at $5^{\circ} \mathrm{C}$ for 10 days. Tenfold serial dilutions were prepared using sterile peptone solution $(0.1 \%)$ for further spread on agar plate to detected typical colonies by biochemical characterization, identification, and plate count (Staphylococcus spp. and Escherichia coli) using the most probable number per gram [24]. Salmonella was investigated according to standard methods [25].

\section{Statistical analysis}

Data for physical and physicochemical analyses are expressed as mean \pm SD $(n=3)$. Differences among treatments were assessed by two way analysis of variance (ANOVA) followed by the Tukey's test using Statistic 7.0 software. In all cases, the significance level adopted was $5 \%$ $(\alpha=0.05)$.

\section{Results and Discussion}

Proximate composition in cobia used in this experiment and their standard deviations was $76.85 \pm 1.26 \%$ moisture, $0.96 \pm 0.02 \%$ ash, $16.85 \pm 1.6 \%$ total proteins and $3.48 \pm 0.32 \%$ total fat. It is known that variations in the chemical composition of marine fishes is closely related to nutrition, living area, fish size, catching season, seasonal and sexual variations as well as other environmental conditions [26]. These variations, might lead to changes in attributes, including taste, odor, texture, color and surface appearance, which control the acceptability of fish as food [27]. The Official Regulations on Industrial Sanitation and Inspection of Animal Products - RIISPOA [28] established the maximum $\mathrm{pH}$ limit for the internal part of fresh fish as 6.5. According to Papadopoulos et al. [29], the $\mathrm{pH}$ value of live fish muscle is close to 7.0. However, post mortem $\mathrm{pH}$ may vary from 6.0 to 7.1 depending on species, fishing season and other factors [30]. In the present study, the initial $\mathrm{pH}$ for Cobia stored during 45 days was 6.4 for all treatments (Figure 1). In atmosphere control (A) condition, was observed an 


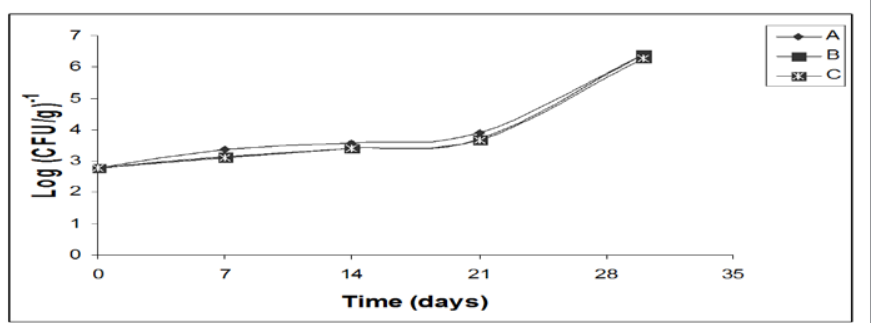

Figure 1: $\mathrm{pH}$ of cobia stored during 45 days in different atmospheres. Where: A (Control); B (vacuum); C (100\% $\left.\mathrm{CO}_{2}\right)$.

increase during the first ( 1 day) and last day (45 day) of storage, when compared with the time of packaging (0 day) (Figure 1$)$. These increases may be due to an accumulation of alkaline compounds, such as ammonia, derived mainly from microbial action [31]. Oppositely, in vacuum (B) and MAP (C) conditions, the $\mathrm{pH}$ dropped from the time of packaging ( 0 days) for all sampling times, remained stable throughout the storage period (Figure 1). However, MAP treatment was significantly lower and more stable when compared with the other two treatments. These results may be related to lower psychrotrophic bacteria counts found in this treatment, probably due to the antimicrobial action of the $\mathrm{CO} 2$ in fish muscle. Arkoudelos et al. [32] analyzing quality attributes of eel (Anguilla anguilla) stored under air and MAP conditions, showed no statistically significant differences on the $\mathrm{pH}$ values for eel during the entire period of storage. According to the authors, $\mathrm{pH}$ examination could not be useful for monitoring eel quality changes. Poli et al. [33] found initial $\mathrm{pH}$ values of 6.4 in fillets of sea bass (Dicentrarchus labrax), very similar to the values found in the present study. Torrieri et al. [34] verified in Dicentrarchus labrax bass a $\mathrm{pH}$ of 6.6 ; once packed in modified atmosphere, the $\mathrm{pH}$ decreases to 6.5-6.3, depending on the storage atmosphere composition. Only samples packed with air as initial gas composition exhibited an increase on $\mathrm{pH}$, which can be attributed to a consequent accumulation of basic substances in the bass muscles. Similar results were reported by Pastoriza et al. [35] and RuizCapillas and Moral [36], supporting the results observed in the present work. Stamatis and Arkoudelos [37] also found similar results to the present study for $\mathrm{pH}$ values in Sardina pilchardus fillets under control, MAP and vacuum packaging at $3^{\circ} \mathrm{C}$. The $\mathrm{pH}$ of MAP and vacuum samples were lower throughout the storage period and static around an initial value of 6.26. For MAP stored fish it is well known that carbon dioxide can be absorbed into fish surface muscle, acidifying it via carbonic acid formation. According to Sikorski et al. [38] pH stability under these conditions may be explained by the buffer effect of the fish muscle This effect is attributed to the presence of soluble proteins, amino acids, trimethylamine and low molecular weight substances which may mask $\mathrm{pH}$ changes such as the slow increase in $\mathrm{pH}$ at the beginning of the degradation and faster towards the end process. This increase, commonly observed in spoiled products, may in part explain the significant differences found towards the end of storage. The TVB-N values of cobia stored during 45 days increased significantly during storage period (Figure 2). However, the increased was higher for atmosphere control condition (A) when compared with (B) and (C) treatments, which had values below the limit established by Brazilian legislation (30 mg $\left.100 \mathrm{~g}^{-1}\right)$. Statistical analysis of TVB-N data showed significant differences $(\mathrm{P}<0.05)$ between cobia stored in air $(\mathrm{A})$, vacuum (B) and MAP (C), after 14 days of storage. However, no significant differences $(\mathrm{P}>0.05)$ were observed between TVB-N values of cobia in (B) and (C) condition during the storage period (45 days). Similar results were reported by Ozogul et al. [39] evaluating sardine (Sardina pilchardus) packaging in modified atmosphere and vacuum. At the beginning of storage, the TVB-N value was $4.9 \mathrm{mg} 100 \mathrm{~g}^{-1}$ for all cobia fillets stored conditions. The release of total volatile bases increased up

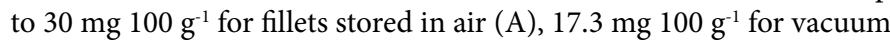
(B) and $16 \mathrm{mg} 100 \mathrm{~g}^{-1}$ for MAP (C) after 30 days of storage. Fraser and Sumar [40] indicated that bacterial catabolism of amino acids in fish muscle results in an accumulation of ammonia and others volatile bases. Fernandez et al. [41] studying Salmo salar under MAP condition, founded no significant differences in TVB-N values during the storage period. The values were also lower than those indicated by technical standards $\left(30 \mathrm{mg} \mathrm{N} 100 \mathrm{mg}^{-1}\right)$. When the total viable counts reached $106 \mathrm{cfu} \mathrm{g}^{-1}$, the TVB-N content was found to be approximately $29 \mathrm{mg}$ $100 \mathrm{~g}^{-1}$ for air (A) conditions. The fast increase of TVB-N at higher microbial numbers indicates substantial deterioration of the fish. MAP (C) condition showed the lowest values of TVB-N. According to Lampila [42] this result could be explained by two factors: the inhibiting effect of $\mathrm{CO}_{2}$ on microbial growth, and the change in flora composition when fish is stored in enriched $\mathrm{CO}_{2}$ atmospheres. Ruiz-Capillas and Moral [36] also observed that TVB-N levels in Merluccius merluccius stored in $\mathrm{CO}_{2}$ atmospheres increased more slowly than in air. The control (air condition) had the highest TVB-N values throughout the storage period exceeding the acceptability limits of $30 \mathrm{mg} 100 \mathrm{~g}$ of muscle $^{-1}$ after 25 days of storage, while the samples packaged in different atmospheres does not exceed this limit throughout the storage period. In accordance with these results, Ruiz-Capillas and Moral [36] founded that all Merluccius merluccius packaged in MAP condition do not

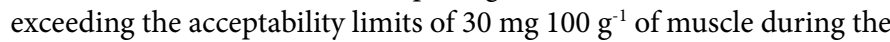
storage period ( 35 days). According to Stamatis and Arkoudelos [37] the TVB-N concentrations of Sardina pilchardus and others fishes contain little carbohydrate in muscle tissues $(<0.5 \%, \mathrm{w} / \mathrm{w})$ that explain the small amounts of lactate produced post mortem. The Figure 3 shows TBA values of cobia stored during 45 days in different conditions (A, B and C). The values remained in the recommended limits $(1.5 \mathrm{mg}$ of malonaldehyde $\mathrm{Kg}$ of muscle ${ }^{-1}$ [ [43,44] during 14 days of storage for control condition (A) and 30 days of storage for $(\mathrm{B})$ and $(\mathrm{C})$ conditions, ( $\mathrm{p}>0.05)$. The TBA results for control (A) indicate that after 14th day of storage rancidity can be detected (TBA greater than $1.6 \mathrm{mg} \mathrm{MA} \mathrm{kg}^{-1}$ ). Generally, lipids of fresh fish stored in ice or under refrigeration, rarely show any tendency towards oxidative rancidity. However, when this fish is stored for long periods of time in atmospheres control with high $\mathrm{O}_{2}$ levels, rancidity could be a problem. The TBA values observed for the vacuum packing treatment (B) were lower at the end of the storage period when compared to the values obtained for the other two treatments (A and C) (Figure 3). This result can probably be explained by the lack of gas in (B) treatment that slows the process of oxidation of

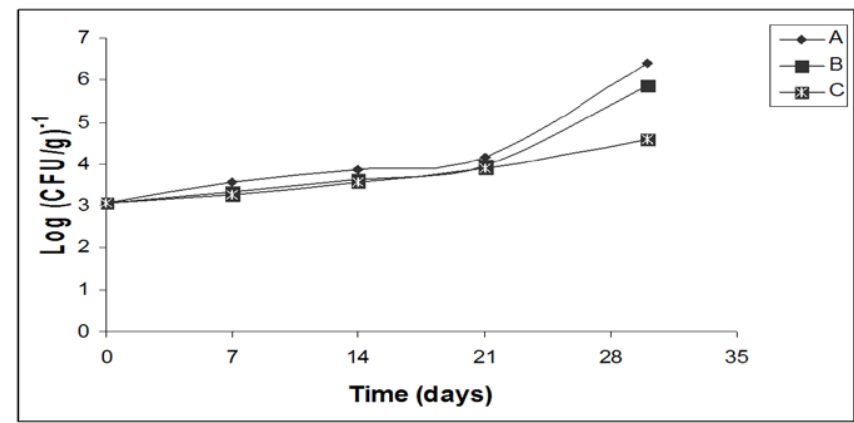

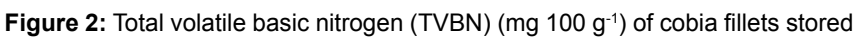
during 45 days in different atmospheres. Where: A (Control); B (vacuum); C $\left(100 \% \mathrm{CO}_{2}\right)$ 


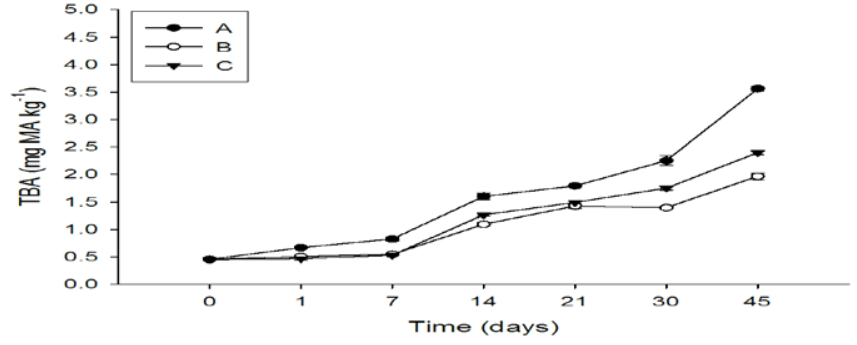

Figure 3: Thiobarbituric acid (TBA) (mg of malonaldehyde $\left.100 \mathrm{~g}^{-1}\right)$ of cobia fillets stored during 45 days in different atmospheres. Where: A (Control); B (vacuum); C $\left(100 \% \mathrm{CO}_{2}\right)$

polyunsaturated fatty acids in this treatment. Treatment (C), kept in atmosphere with high CO2 concentrations (100\%), had TBA levels of $1.75 \mathrm{mg} \mathrm{MA} / \mathrm{kg}$, after 30 days of storage. Studying hake (Merluccius merluccius) Ruiz-Capillas and Moral [36] observed greater TBA amounts for richer $\mathrm{CO}_{2}$ atmospheres conditions, probably due to a synergistic action between $\mathrm{CO}_{2}$ and $\mathrm{O}_{2}$, which facilitate polyunsaturated fatty acid autooxidation. Soccol et al. [45] also observed similar behavior in modified atmospheres. Bacteria of the genus Salmonella $s p p$. does not occur originally in fish, just when is introduced during handling or contact with contaminated water. The original habitat of this genus of bacteria is the intestinal tract of humans and warm blooded animals and their presence indicates a possible fecal contamination. Fish caught in clean waters are generally exempt from this type of bacteria. Their presence is due to the contact with infected fish, poorly cleaned surfaces and cross contamination [46,47]. In the present work, the presence of Salmonella ssp. was not detected in any samples, indicating good hygiene and product safety.

Although Brazilian legislation does not establish reference values for the presence of Escherichia coli in fish, quantitative knowledge of this microorganism is an important indicator of sanitary quality and fitness for human consumption of fish. Escherichia coli counts found in cobia fillets packaged in different atmospheres were below to $0.3 \mathrm{NMP}$ $\mathrm{g}^{-1}$ or $>102 \mathrm{CFU} \mathrm{g}^{-1}$ of sample for all treatments (A, B and C), showing that the fillets studied had good production and manipulation practices according the standards established by ICMSF which maintain the maximum value of $103 \mathrm{NMP} \mathrm{g}^{-1}$ for fresh fish refrigerated at $4^{\circ} \mathrm{C}$ or frozen at $-18^{\circ} \mathrm{C}$. The growth curves of aerobic mesophilic microorganisms of cobia fillets packaged in different modified atmospheres is shown in Figure 4 . We can observe that the count of mesophilic microorganisms increased with the time of storage in all treatments with a significant difference between the first and last day of analysis in all treatments. A significant difference between treatment $(A)$ and $(C)$ was also observed after 30 days of storage, showing that the use of different gases were effective to reduce microbial growth. Similarly, Cortez-Vega et al. [48] studying beef and raw chicken breast demonstrated the effective using of different gases to control microorganism's growth. Regarding the aerobic psychrotrophic microorganisms growth, no limits were establish in Brazilian legislation, however it is also known that high counts of this kind of microorganisms contribute to the reduction of the product lifetime. The ICMSF establishes counts less than 106-107 $\mathrm{cfu} \mathrm{g}^{-1}$ as safe standards for consumption [49]. In order to increase the shelf life of commercial products, the initial microbiological counts must be reduced using strict hygienic conditions in the industry. In addition, to reduce the microbial growth rate, the storage temperature should be maintained at $1.5^{\circ} \mathrm{C}$ instead of $0^{\circ} \mathrm{C}$. In the present work, the growth curve of aerobic psychrotrophic microorganisms (Figure 5) showed a growth during the storage time. Treatment (A) showed an increase of approximately $68 \%$ between the first and last day of storage while treatment (C) showed $40.75 \%$ growth over the same period. Many microorganisms of aerobic spoilage have their growth inhibited by the presence of small quantities of $\mathrm{CO}_{2}(20 \%)$, increasing the product shelf life with the increasing $\mathrm{CO}_{2}$ concentrations [50]. In the present study, it was observed that the use of $\mathrm{CO}_{2}$ with other gases increased the life span of cobia fillets over the control sample. The growth curve for Staphylococcus spp. in cobia fillets stored under refrigeration conditions during 30 days (Figure 6) showed an increase in Staphylococcus ssp. microorganisms for all treatments (A, B and C) over the entire period with no significant difference between the treatments after 30 days of storage. The results showed that the Staphylococcus ssp. count was not significantly $(p>0.05)$ affected by the treatments or the storage period, with values above $103 \mathrm{CFU} \mathrm{g}^{-1}$ after 30 days of storage. The Compendium of Norms and Standards for Food [51] established a maximum of 103 Staphylococcus coagulase $(+) \mathrm{g}$ of fish as standards for fresh refrigerated fish. Values of color $\left(\mathrm{L}^{*}, \mathrm{a}^{*}, \mathrm{~b}^{*}\right)$ and texture of cobia fillets stored under refrigeration are reported in Table 1 . The results demonstrated a decrease in lightness $\left(\mathrm{L}^{*}\right)$ during the storage days. The decrease of $\mathrm{L}^{\star}$ leads to change in the fillets color, whereas values near to zero indicate darker

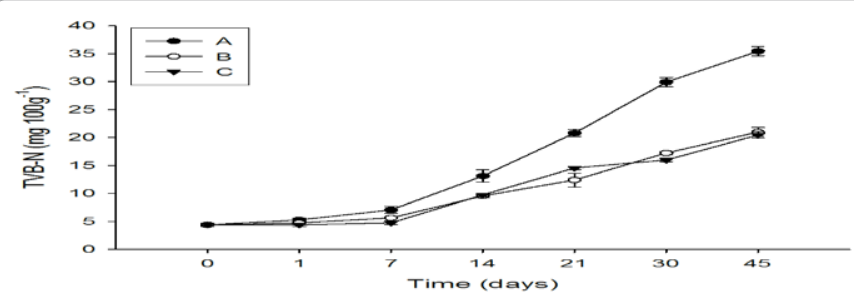

Figure 4: Growth curve of aerobic mesophilic microorganisms of cobia fillets packaged in different atmospheres. Where: A (Control); B (vacuum); C (100\% $\mathrm{CO}_{2}$ ).

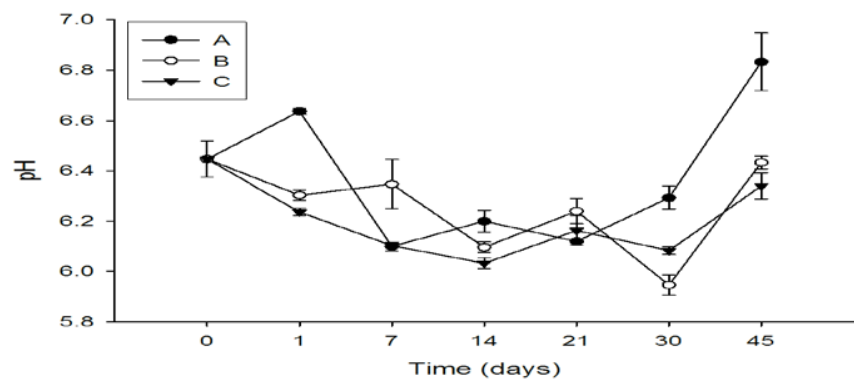

Figure 5: Growth curve of psychrotrophic microorganisms of cobia fillets packaged in different atmospheres. Where: A (Control); B (vacuum); C (100\% $\mathrm{CO}_{2}$ ).

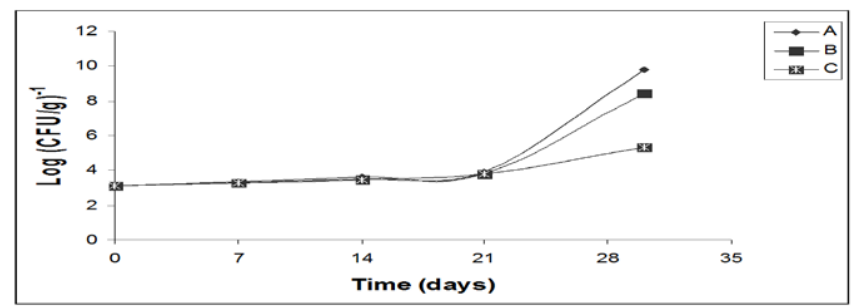

Figure 6: Growth curve of Staphylococcus spp. microorganisms of cobia fillets packaged in different atmospheres. Where: A (Control); B (vacuum); C (100\% $\mathrm{CO}_{2}$ ). 
Citation: Junior MAG, Jorge MB, Cortez-Vega WR, Pizato S, Prentice-Hernández C (2015) Quality Attributes of Cobia (Rachycentron canadum) Fillets Chilled and Packaged in Modified Atmospheres. J Food Process Technol 6: 445. doi:10.4172/2157-7110.1000445

Page 5 of 7

\begin{tabular}{|c|c|c|c|c|c|}
\hline \multirow{2}{*}{ Time (days) } & \multirow{2}{*}{ Treatments } & \multicolumn{3}{|c|}{ Color } & \multirow{2}{*}{ Texture } \\
\hline & & $L^{*}$ & $a^{*}$ & $\mathbf{b}^{*}$ & \\
\hline \multirow{3}{*}{0} & A & $66.85 \pm 1.03^{\mathrm{aBC}}$ & $0.73 \pm 0.12^{\mathrm{aB}}$ & $1.46 \pm 0.24^{\mathrm{ac}}$ & $6.61 \pm 1.2^{\mathrm{aA}}$ \\
\hline & B & $66.85 \pm 1.03^{\mathrm{aA}}$ & $0.73 \pm 0.12^{\mathrm{aAB}}$ & $1.46 \pm 0.24^{\mathrm{ac}}$ & $6.61 \pm 1.2^{\mathrm{aA}}$ \\
\hline & C & $66.85 \pm 1.03^{\mathrm{aA}}$ & $0.73 \pm 0.12^{\mathrm{aAB}}$ & $1.46 \pm 0.24^{\mathrm{aD}}$ & $6.61 \pm 1.2^{\mathrm{aA}}$ \\
\hline \multirow{3}{*}{1} & A & $66.23 \pm 0.71^{\mathrm{aBC}}$ & $0.61 \pm 0.10^{\mathrm{bB}}$ & $1.57 \pm 0.15^{\mathrm{ac}}$ & $6.61 \pm 1.2^{\mathrm{aA}}$ \\
\hline & B & $66.15 \pm 0.66^{\mathrm{aA}}$ & $0.73 \pm 0.21^{\mathrm{abAB}}$ & $1.42 \pm 0.06^{\mathrm{ac}}$ & $6.61 \pm 1.2^{\mathrm{aA}}$ \\
\hline & C & $66.10 \pm 1.20^{\mathrm{aA}}$ & $1.01 \pm 0.08^{\mathrm{aA}}$ & $1.56 \pm 0.21^{\mathrm{aD}}$ & $6.61 \pm 1.2^{\mathrm{aA}}$ \\
\hline \multirow{3}{*}{7} & A & $65.63 \pm 0.62^{\mathrm{aBC}}$ & $0.61 \pm 0.21^{\mathrm{aB}}$ & $2.62 \pm 0.19^{\mathrm{aBC}}$ & $4.19 \pm 0.7^{\mathrm{cA}}$ \\
\hline & $B$ & $66.32 \pm 0.29^{\mathrm{aA}}$ & $0.52 \pm 0.19^{\mathrm{aB}}$ & $2.17 \pm 0.83^{\mathrm{aBC}}$ & $5.08 \pm 1.37^{\mathrm{abA}}$ \\
\hline & $\mathrm{C}$ & $62.91 \pm 0.97^{\mathrm{bB}}$ & $-0.51 \pm 0.07^{\mathrm{bc}}$ & $1.72 \pm 0.22^{\mathrm{aD}}$ & $4.09 \pm 1.3^{\mathrm{bA}}$ \\
\hline \multirow{3}{*}{14} & A & $72.44 \pm 0.51^{\mathrm{aA}}$ & $1.35 \pm 0.09^{a A}$ & $3.56 \pm 0.42^{\mathrm{bB}}$ & $3.45 \pm 0.2^{\mathrm{bcB}}$ \\
\hline & B & $65.74 \pm 0.14^{\mathrm{bA}}$ & $-0.73 \pm 0.21^{c c}$ & $2.29 \pm 0.12^{\mathrm{CABC}}$ & $5.01 \pm 0.45^{\mathrm{abA}}$ \\
\hline & $\mathrm{C}$ & $60.38 \pm 0.46^{c c}$ & $0.03 \pm 0.01^{\mathrm{bBC}}$ & $6.56 \pm 0.27^{\mathrm{ac}}$ & $3.27 \pm 0.23^{\mathrm{bB}}$ \\
\hline \multirow{3}{*}{21} & A & $67.86 \pm 1.43^{\mathrm{aB}}$ & $1.04 \pm 0.33^{\mathrm{aAB}}$ & $3.34 \pm 0.92^{\mathrm{bBC}}$ & $3.01 \pm 0.14^{\mathrm{bcB}}$ \\
\hline & $B$ & $65.45 \pm 0.51^{\mathrm{bA}}$ & $0.77 \pm 0.32^{\mathrm{aAB}}$ & $2.61 \pm 0.31^{\mathrm{bAB}}$ & $4.96 \pm 0.27^{\mathrm{abA}}$ \\
\hline & $\mathrm{C}$ & $58.84 \pm 0.37^{\mathrm{CCD}}$ & $-1.33 \pm 0.16^{\mathrm{bD}}$ & $6.87 \pm 0.33^{\mathrm{ac}}$ & $3.19 \pm 0.2^{\mathrm{bB}}$ \\
\hline \multirow{3}{*}{30} & A & $65.36 \pm 2.23^{\mathrm{aBC}}$ & $1.01 \pm 0.37^{\mathrm{aAB}}$ & $6.64 \pm 1.29^{\mathrm{aA}}$ & $2.77 \pm 0.12^{\mathrm{bcB}}$ \\
\hline & $\mathrm{B}$ & $65.36 \pm 0.32^{\mathrm{aA}}$ & $1.15 \pm 0.14^{\mathrm{aA}}$ & $2.88 \pm 0.17^{\mathrm{bAB}}$ & $4.58 \pm 0.13^{\mathrm{abA}}$ \\
\hline & C & $58.53 \pm 0.36^{\mathrm{bCD}}$ & $-3.52 \pm 0.67^{b F}$ & $7.92 \pm 0.56^{\mathrm{aB}}$ & $2.92 \pm 0.7^{\mathrm{bB}}$ \\
\hline \multirow{3}{*}{45} & A & $63.35 \pm 1.97^{\mathrm{ac}}$ & $1.41 \pm 0.07^{\mathrm{aA}}$ & $6.96 \pm 0.75^{\mathrm{bA}}$ & $2.05 \pm 0.08^{\mathrm{cB}}$ \\
\hline & B & $62.65 \pm 0.78^{\mathrm{aA}}$ & $-0.19 \pm 0.05^{\mathrm{cB}}$ & $3.28 \pm 0.16^{\mathrm{cA}}$ & $3.93 \pm 0.25^{\mathrm{aA}}$ \\
\hline & $\mathrm{C}$ & $57.44 \pm 0.11^{\mathrm{bD}}$ & $-2.28 \pm 0.13^{\mathrm{CE}}$ & $9.61 \pm 0.36^{\mathrm{aA}}$ & $2.58 \pm 0.35^{\mathrm{bB}}$ \\
\hline
\end{tabular}

Where: A (Control); B (vacuum); C (100\% CO2). Means followed by the same letter in the column and capital letter in the line did not differ by Tukey Test $(\mathrm{P}<0.05)$ Table 1: Color values $\left(\mathrm{L}^{*}\right)$, Chroma $\mathrm{a}^{*}$, Chroma $\mathrm{b}^{*}$ and texture values $(\mathrm{N})$ of cobia fillets using different packaging stored under refrigeration.

fillets. In the present work, the use of $\mathrm{CO}_{2}$ was not effective for reducing browning of cobia fillets. However, different results were found by Cortez-Vega et al. [49] that demonstrated the efficacy of $\mathrm{CO}_{2}$ compared to the control sample in delaying browning raw chicken breast fillets. Poli et al. [33] also found higher brightness values at the beginning and in the end of the storage period in European sea bass fillets in relation to the control samples. Analysis of Chroma ${ }^{*}$ (Table 1) indicate a decrease in values of all treatments during the storage days. This decrease in the red color of samples indicates a trend to darken (tendency to green). In 45 days of analysis, no significant difference was observed between treatments (B) and (C). These results is in agreement with Cortez-Vega et al. [49] who also observed a decrease in the values of Chroma $a^{*}$ in raw chicken breast fillets. Regarding Chroma $b^{\star}$ values (Table 1 ), was observed an increase in all treatments. However, MAP treatment (C, $100 \% \mathrm{CO}_{2}$ ) showed the higher value of Chroma $\mathrm{b}^{*}$ compared to the control sample (A), demonstrating that this gas was not effective in maintaining cobia fillets color. This increase shows a tendency to darker color (tendency to yellow) and a possible degradation of cobia fillets. The texture analyses (Table 1) showed a decreasing during the storage days for all treatments. The control treatment (A) showed the higher reduction in texture (68.98\%), followed by (C) (60.96\%) and (B) $(40.54 \%)$ after 45 days of storage under refrigeration. According to Dhananjayan et al. [52], the decrease in cutting force is related to microbial deterioration during the storage period when nutrient uptake by bacteria occurs and the fibers break down more easily at lower shear strength. Fernández et al. [41] studied the combined effect of modified atmosphere packaging with additives, estimated that the shelf life for salmon (Salmo salar) was 27 days considering the texture of fillets as parameter. The authors showed that this type of treatment was efficient to maintaining the texture for longer time. However, in the present work, vacuum packaging (B) showed lower decrease of texture during the evaluated period. The decrease of texture found in this study for treatment $(\mathrm{A})$ in relation to $(\mathrm{B})$ and $(\mathrm{C})$ are according to data reported by Cortez-Vega et al. [49], who also found differences between the first and last day of storage for the control and the treatment of $100 \% \mathrm{CO}_{2}$. The same authors founded lower decrease in raw chicken breast fillets texture over other treatments.

\section{Conclusions}

From the results of the chemical and microbiological analyses, it can be concluded that the treatments (B) and (C) presented satisfactory results for the storage test period. MAP treatment $(\mathrm{C})$, different for the other ones, presented discolored fillets with softer texture. The presence of Salmonella and Escherichia coli was not detected during the storage period. Vacuum packing, proved as the best treatment, maintained the best stability condition for chemical, microbiological and sensory characteristics throughout the experiment, extending the shelf life of cobia fillets for 30 days.

\section{Acknowledgments}

The authors acknowledge the Nautilus Farm, Ilha Grande, RJ, Brazil; CNPq; MPA and FAPEAM for the financial support.

\section{References}

1. Liao IC, Leaño EM (2007) Cobia aquaculture: research, development and commercial production. World Aquaculture Society. Louisiana, USA.

2. Duncan M, Craig SR, Lunger AN, Kuhn DD, Salze G, et al. (2007) Bio impedance assessment of body composition in cobia (Rachycentron canadum). Aquaculture 271: 432-438

3. Lunger AN, Mclean E, Gaylord TG, Craig SR (2007) Taurine addition to alternative dietary proteins used in fish meal replacement enhances growth of juvenile cobia (Rachycentron canadum). Aquaculture 271: 401-410.

4. Leistner L (1992) Food preservation by combined methods. Food Research International 25: 151-158.

5. Fletcher GC, Statham JA (1988) Shelf-life of sterile yellow-eyed mullet (Aldrichetta forsteri) at $4^{\circ} \mathrm{C}$. Journal of Food Science 53: 1030-1035.

6. Sivertsvik M, Jeksrud WK, Rosnes JT (2002) A review of modified atmosphere packaging of fish and fishery products - significance of microbial growth activities and safety. International Journal of Food Science and Technology 37 107-127. 
Citation: Junior MAG, Jorge MB, Cortez-Vega WR, Pizato S, Prentice-Hernández C (2015) Quality Attributes of Cobia (Rachycentron canadum) Fillets Chilled and Packaged in Modified Atmospheres. J Food Process Technol 6: 445. doi:10.4172/2157-7110.1000445

7. Dalgaard $P(2000)$ Fresh and lightly preserved seafood. Shelf-life evaluation of foods. Gaithersburg, Md.: Aspen Publishers, Inc.

8. Dalgaard P (1995) Qualitative and quantitative characterization of spoilage bacteria from packed fish. International Journal of Food Microbiology 26: 319 33.

9. Emborg J, Laursen BG, Rathjen T, Dalgaard P (2002) Microbial spoilage and formation of biogenic amines in fresh and thawed modified atmosphere packed salmon (Salmo salar) at $2^{\circ} \mathrm{C}$. Journal of Microbiology 92: $790-799$.

10. Chouliara E, Badeka A, Savvaidis I, Kontominas MG (2008) Combined effect of irradiation and modified atmosphere packaging on shelf-life extension of chicken breast meat: Microbiological, chemical and sensory changes. European Food Research and Technology 226: 877-888.

11. Rosnes JT, Kleiberg GH, Sivertsvik M, Lunestad BT, Lorentzen G (2006) Effect of modified atmosphere packaging and super chilled storage on the shelf life of farmed ready-to-cook spotted wolf-fish (Anarhichas minor). Packaging Technology and Science 19: 325-333.

12. Soccol MCH, Oetterer M (2003) Use of modified atmosphere in seafood preservation. Brazilian Archives of Biology and Technology 46: 569-580.

13. Sivertsvik M (2007) The optimized modified atmosphere for packaging of prerigor filleted farmed cod (Gadus morhua) is $63 \mathrm{ml} / 100 \mathrm{ml}$ oxygen and 37 $\mathrm{ml} / 100 \mathrm{ml}$ carbon dioxide. LWT- Food Science and Technology 40: 430-438.

14. Rotabakk BT, Lekang OI, Sivertsvik M (2008) Volumetric method to determine carbon dioxide solubility and absorption rate in foods packaged in flexible or semi rigid package. Journal of Food Engineering 84: 499-509.

15. Gonzalez C (2000) Effect of the use of modified atmospheres on the extension of shelf life of cold fresh Atlantic salmon. In Eight International Congress on Engineering and Food. México.

16. Pastoriza L, Sampedro G, Herrera JJ, Cabo ML (1996) Effect of carbon dioxide atmosphere on microbial growth and quality of salmon slices. Journal of the Science of Food and Agriculture 72: 348-352.

17. Hoz L, Lopez-Galvez DE, Fernandez M, Hierro E, Ordonez JA (2000) Use of carbon dioxide enriched atmospheres in the refrigerated storage $\left(2^{\circ} \mathrm{C}\right)$ of salmon (Salmo salar) steaks. European Food Research and Technology 210 179-188.

18. Sivertsvik M, Rosnes JT, Vorre A, Randell K, Ahvenainen R, et al. (1999) Quality of whole gutted salmon in various bulk packages. Journal of Food Quality 22: 387-401.

19. AOAC (2000) Official Methods of Analysis. Association of Official Analytical Chemists. 16th ed., Arlington.

20. Jesus RS (1999) Estabilidade de minced fish de peixes amazônicos durante o congelamento. Tese. Faculdade de Ciências Farmacêuticas, USP, São Paulo.

21. Tarladgis BG, Watts BM, Younathan MT (1960) A distillation method for the quantitative determination of malonaldehyde in rancid foods. The Journal of the American Oil Chemists' Society 37: 44-48.

22. IAL-Instituto Adolfo Lutz (1985) Normas Analíticas Métodos químicos e físicos para análise de alimentos. São Paulo, Brazil

23. Sigurgisladottir S, Hafsteinsson $\mathrm{H}$, Jonsson A, Lie O, Nortvedt R, et al. (1999) Textural properties of raw salmon fillets as related to sampling method. Journal of Food Science 64: 99-104.

24. USDA/FSIS-United States Department of Agriculture/Food Safety and Inspection Service (1998) Microbiology Laboratory Guidebook, 3rd Ed., USDA FSIS, Washington, DC.

25. ISO 6579 (1993) Microbiology-General Guidance on Methods for the Detection of Salmonella. International Organization of Standardization, Geneva, Switzerland.

26. Gonçalves AA (2010) Tecnologia do pescado: ciência, tecnologia, inovação e legislação. (Ed) Rio de Janeiro: Atheneu.

27. Flick GR, Martin RE (1992) Advances in Seafood Biochemistry, Composition and Quality. Technomic Publishing Co., Lancaster.

28. BRASIL (2002) Ministério da Agricultura, Pecuária e Abastecimento. Regulamento da inspeção industrial e sanitária de produtos de origem animalRIISPOA. Pescados e derivados, Brasília.

29. Papadopoulos V, Chouliara I, Badeka A, Savvaidis IN, Kontominas MG
(2003) Effect of gutting on microbiological, chemical and sensory properties of aquaculture sea bass (Dicentrarchus labrax) stored in ice. Food Microbiology 20: $411-420$.

30. Simeonidou S, Govaris A, Vareltzis K (1998) Quality assessment of seven Mediterranean fish species during storage on ice. Food Research International 30: 479-484.

31. Hebard CE, Flick GJ, Martin RE (1982) Occurrence and significance of trimethylamine oxide and its derivates in fish and shellfish, in Chemistry and Biochemistry of Marine Food Products. Westport.

32. Arkoudelosa J, Nikolaos S, Samarasa F (2007) Quality attributes of farmed eel (Anguilla anguilla) stored under air, vacuum and modified atmosphere packaging at $0-1{ }^{\circ} \mathrm{C}$. Food Microbiology 24: 728-735.

33. Poli BM, Messini A, Parisi G, Scappini F, Vigiani V, et al. (2006) Sensory, physical, chemical and microbiological changes in European sea bass (Dicentrartchus labrax) fillets packed under modified atmosphere/air or prepared from whole fish stored in ice. International Journal of Food Science and Technology 41: 444-454.

34. Torrieri ES, Cavella S, Villani F, Masi P (2006) Influence of modified atmosphere packaging on the chilled shelf life of gutted farmed bass (Dicentrarchus labrax) Journal of Food Engineering 77: 1078-1086.

35. Pastoriza L, Sampedro G, Herrera JJ, Cabo ML (1998) Influence of sodium chloride and modified atmosphere packaging on microbiological, chemical, and sensorial properties in ice storage of slices of hake (Merluccius merluccius) Food Chemistry 61: 23-28.

36. Ruiz-Capillas C, Moral A (2001) Chilled bulk storage of gutted hake (Merluccius merluccius) in $\mathrm{CO}_{2}$ and $\mathrm{O}_{2}$ enriched controlled atmospheres. Food Chemistry 74: $317-325$

37. Stamatis N, Arkoudelos JS (2007) Effect of modified atmosphere and vacuum packaging on microbial, chemical and sensory quality indicators of fresh, filleted Sardina pilchardus at $3^{\circ} \mathrm{C}$. Journal of the Science of Food and Agriculture 87 : 1164-1171.

38. Sikorski ZE, Kolakowska A, Burt JR (1994) Cambios bioquímicos y microbianos subsiguientes a la captura. Tecnologia de los productos del mar: recursos, composición y conservación. Zaragoza: Acribia. 4: 73-101.

39. Özoğul F, Polat A, Özoğul Y (2004) The effects of modified atmosphere packaging and vacuum packaging on chemical, sensory and microbiological changes of sardines (Sardina pilchardus). Food Chemistry 85: 49-57.

40. Fraser OP, Sumar S (1998) Compositional changes and spoilage in fish microbiological induced deterioration. Nutrition and Food Science 98: 325-329.

41. Fernández K, Aspe E, Roeckel M (2009) Shelf-life extension on fillets of Atlantic salmon (Salmo salar) using natural additives, super chilling and modified atmosphere packaging. Food Control 20: 1036-1042.

42. Lampila LE (1991) Modified atmosphere packaging. New York, USA: Van Nostrand Reinhold.

43. Al-Kahtani HA, Abu-Tarboush HM, Bajaber AS (1996) Chemical changes afte irradiation and post-irradiation storage in tilapia and Spanish mackerel. Journal of Food Science 61: 729-733.

44. Osawa CC, Felício PE, Gonçalves LAG (2005) Teste de TBA aplicado a carnes e derivados: métodos tradicionais, modificados e alternativos. Química Nova. 28: $655-663$.

45. Soccol MCH, Oetterer M, Gallo CR, Spoto MHF, Biato DO (2005) Effects of modified atmosphere and vacuum on the shelf life of Tilapia (Oreochromis niloticus) fillets. Brazilian Journal of Food Technology 8: 7-15

46. Martins CVB, Vaz SK, Minozzo M (2002) Aspectos sanitários de pescados comercializados em pesque-pagues de Toledo (PR). Revista Higiene Alimenticia 16: 51-56.

47. Bartholomeu DAFS, Dallabona BR, Macedo REF, Kirschnik PG (2011) Contaminação microbiológica durante as etapas de processamento de filé de tilápia (Oreochromis niloticus). Archives of Veterinary Science 16: 21-30.

48. Cortez-Vega WR, Pizato S, Prentice C (2012) Quality of raw chicken breast stored at $5^{\circ} \mathrm{C}$ and packaged under different modified atmospheres. Journal of Food Safety 32: 360-368.

49. ICMSF (1986) International Commission on Microbiological Specifications for Foods. Sampling for microbiological analysis: Principles and specific applications. 2nd ed. London: Blackwell Scientific Publications. 
Citation: Junior MAG, Jorge MB, Cortez-Vega WR, Pizato S, Prentice-Hernández C (2015) Quality Attributes of Cobia (Rachycentron canadum) Fillets Chilled and Packaged in Modified Atmospheres. J Food Process Technol 6: 445. doi:10.4172/2157-7110.1000445

Page 7 of 7

50. Rotabakk BT, Birkeland S, Jeksrud WK, Sivertsvik M (2006) Effect of modified atmosphere packagingand soluble gas stabilization on the shelf life of skinless chicken breast fillets. Journal of Food Science 71: 124-131.

51. Brasil (2001) Ministério da Saúde. Resolução RDC n¹2, de 02 de janeiro de
Aprova o Regulamento Técnico sobre padrões microbiológicos para alimentos. Diário Oficial [da] República Federativa do Brasil. Brasília, DF, Seção 1: 46-53.

52. Dhananjayan R, Han IY, Acton JC, Dawson PL (2006) Growth depth effects of bacteria in ground Turkey meat patties subjected to high carbon dioxide or high oxygen atmospheres. Poultry Science 85: 1821-1828. 